\title{
津波波源内の海面擾乱に関する 水理実験および数値計算
}

\author{
藤原 岳大 1 坂本 $\quad$ 匡史 2 ・高橋 智幸 3 \\ 1学生会員 関西大学大学院 社会安全研究科防災・減災専攻（广569-1098 大阪府高槻市白梅町7-1） \\ E-mail:k963726@kansai-u.ac.jp \\ 2非会員 コベルコシステム株式会社（广 657-0845 兵庫県神戸市灘区岩屋中町4-2-7） \\ 3正会員 関西大学教授 社会安全学部（テ569-1098 大阪府高槻市白梅町7-1）
}

\begin{abstract}
海洋レーダにより津波伝播を観測できることは, 日向ら ${ }^{1)} に よ る$ 紀伊水道での津波伝播と副振動の観測に よって実証された，現在ではさらに津波波源を海洋レーダにより観測することで，津波警報の信頼性向上 や迅速な激甚被災地探索が可能になると期待されている。海洋レーダにより津波波源を観測するためには, 津波波源内の表面流速や水位変動の特徴を明らかにする必要がある. 本研究では, 巨大地震のP波によっ て発生する海面擾乱に着目して, 水理実験と 3 次元数值計算を実施した. 水理実験では底面振動に伴い, パラメトリック励振や振動台の振動数に対応した水面の擾乱が発生することを明らかにした. また, 実海 域スケールにおける数值計算から，P波による海底振動の振動数に対応した海面擾乱が発生することを明 らかにした。
\end{abstract}

Key Words : oceanographic radar, tsunami source ditection, P-wave, OpenFOAM, ocean bottom seismometer

\section{1.はじめに}

Barrick ${ }^{2}$ が提唱した海洋レーダによる津波伝播観測の 可能性は, 日向ら $)^{1)} よ る$ 紀伊水道でのHF海洋レーダを 使った津波伝播と副振動の観測により実証された。海洋 レーダの観測距離は使用する周波数によって異なるが, $9.2 \mathrm{MHz}$ 帯の場合は沿岸200キロ程度までの海域を面的に 観測できる. 門迴ら ことで，南海トラフ巨大地震による津波波源域全体を観 測範囲に含むことができ，大すべり域や超大すべり域を 検知できることを示している.

海洋レーダを用いて津波波源の不均質性を把握するこ とにより，巨大地震の大すべり域などにより局所的に津 波が高くなっている地点を津波到達前に知ることができ ると期待される. 現行の津波警報は地震波解析結果と GPS波浪計の観測データ等を基にして都道府県単位で発 表されているが，津波波源を直接観測することで，より 高解像度の防災情報が提供可能になると考えられる.ま た，巨大地震ほど大きくなる長周期地震動が強震計では 観測できないことによって生じるマグニチュードの過小 評価やそれに伴う津波警報の過小評価のリスクを減らせ ると期待される，さらに，沿岸部での津波高を迅速に把 握することにより, 激甚被災地の早期探索や情報の空白
域での被災状況の予測が可能になる.

海洋レーダを用いて津波波源観測を行うためには，ま ず津波波源内の海面の状態を明らかにすることが必要で ある。これまで津波波源を直接，定量的に観測した事例 はなく，観測する方法についてもまだ確立されていない． しかし，断層運動に伴う急激な海底変動による海震を観

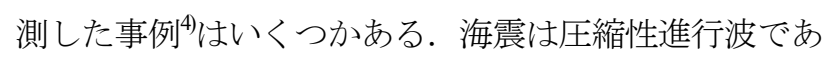
るP波が水中を伝播することで, 海面において地震のよ うな振動を発生させる現象である。この様な海面擾乱の 波長が, 海洋レーダの送信波の半波長となると後方散乱

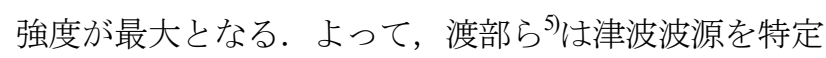
する指標になると考えている. そこで, 本研究では, 水 理実験と数值計算により，P波によって発生する海面擾 乱の特性を調べることを目的とした。

\section{2. 地震波形解析}

津波波源付近の海底変動を知るため，2011年東北地方 太平洋沖地震 (以下, 東北地震) の震源域北縁部に設置 されていた東京大学地震研究所の海底地震計（OBS1） が観測したP波を対象に地震波形解析を実施した。鉛直 方向に発生した地震動が海面擾乱に最も影響を与えると 考えられることから, 本研究では鉛直方向の地震動を対 


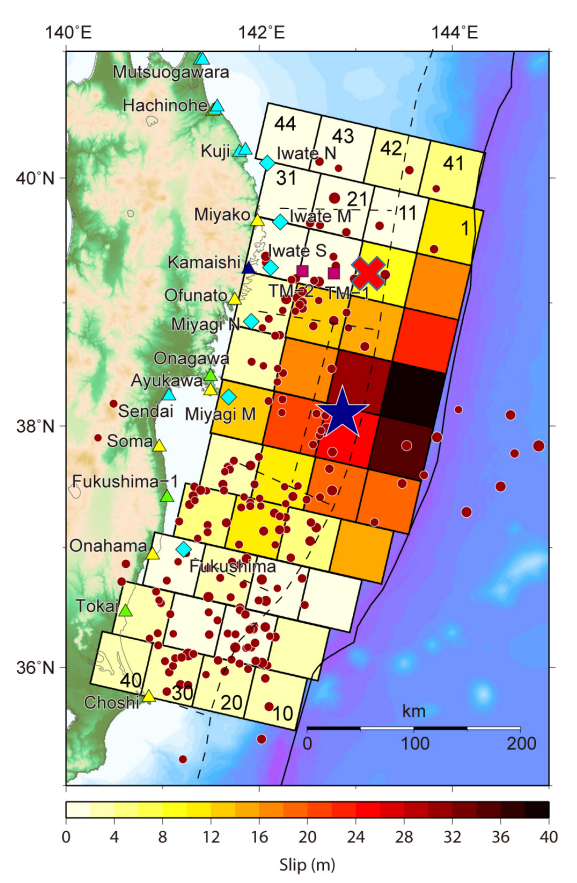

図-1 海底地震計の位置, 藤井らの による東北地震の震源とす ベり量分布（藤井らのの図に加筆），丸印は震源，X印 はOBS1の位置，の印は本震一日後に発生したM5以上の

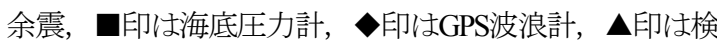
潮所と波浪計を示寸

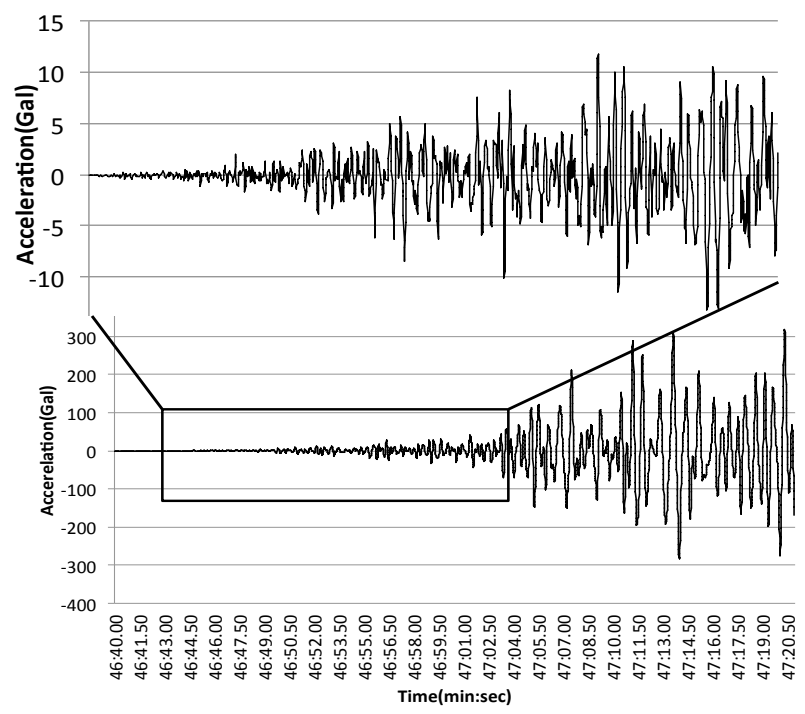

図-2 OBS1が観測した東北地震の波形（下：P波およびS波， 上 : P波のみを抽出）

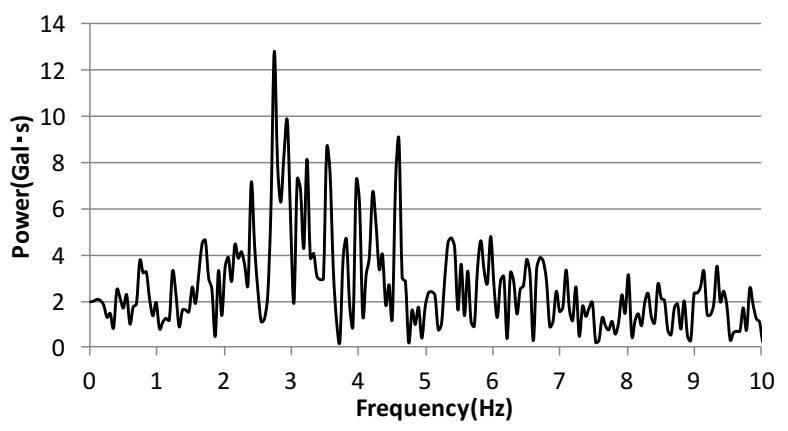

図-3 P波のスペクトル分布
象に高速フーリエ変換によるスペクトル解析を行った.

OBS1の位置と東北地震の震源及びすべり量分布のの関 係を図-1に示す. OBS1付近でのすべり量は数mであり， 大きな津波を発生させた海溝軸付近に比べると小さい. よって，P波の振幅を知るためには最適な場所とはいえ ないが，振動数については参考にできると考えられる.

OBS1が観測した地震波形を図一2の下図に示す。地震 発生初期の加速度は10Gal程度であるが，その後は数百 Gallまで増大する. 本研究はP波に注目しているため, 初期の 20 秒間をP波として抽出した（図-2の上図）。な お，移動平均により周期 2 秒以上の波形は取り除いてあ る.P波のスペクトル解析結果を図-3に示すが，2.7Hzか ら4.5Hzまでの振動数が顕著に発生していたことわかる. よって, 次の水理実験においてはこの周波数帯を含む底 面振動を発生させることとした.

\section{3. 水理実験}

\section{(1) 実験装置, 実験条件および解析方法}

OBS1の観測した東北地震波形のスペクトル分布をも とに，巨大地震によるP波を再現できる水中振動台を備 えた実験水槽を開発した．図-4に実験水槽を示すが，縦 $100 \mathrm{~cm}$, 横 $100 \mathrm{~cm}$, 高さ $70 \mathrm{~cm}$ で, 底面中央部に水中振動 台（直径 $10 \mathrm{~cm}$ の円形）を設置した。なお，実験水槽の 固有振動数は $1.2 \mathrm{~Hz}$ である.

水中振動台の入力波は，複雑な地震波を単純化するた めに鉛直方向の $\sin$ 波とした. 入力波の振動数は $1 \mathrm{~Hz}$ から $9 \mathrm{~Hz}$ まで1Hzずつ，振幅ついては全振幅で $1 \mathrm{~cm}$ から $4 \mathrm{~cm}$ ま

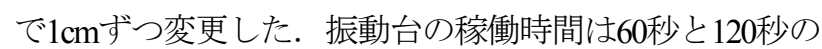
2種類とした. 水深を $30,50,70 \mathrm{~cm}$ と変化させ，全 216 ケ 一スの実験を実施した.

図-5に計測地点と水中振動台を示すが，水槽中心に測 線 $\mathrm{AB}$ 間を設け，水位と流速を測定した。測線には，実 験水槽の上を通るように鉄パイプを設置した。ただし， 水中振動台の振動が測線に影響を与えないように，実験 水槽から $3 \mathrm{~m}$ 離れた地点に設置した脚立に鉄パイプを載 せ，天井からロープで固定した。計測地点a1からa6に, 静電容量式水位計（JFEアレック株式会社製ACH-600RS） と電磁流速計（JFEアレック株式会社製ACM3-RS）を設 置し，水位と流速（水深 $2 \mathrm{~cm}$ ）を測定した。測定のサン プリング間隔は 0.05 秒とし, 移動平均により周期が 1 秒 以上（入力波が $2 \mathrm{~Hz}$ 以上の場合）または 2 秒以上（入力 波が1Hzの場合）の波を取り除いた後，スペクトル解析 を実施した。

\section{(2) 等方性亡再現性の確認}

水理実験の等方性を確認するため，水深 $70 \mathrm{~cm}$, 振幅 $3 \mathrm{~cm}$, 振動数 $6 \mathrm{~Hz}$ の条件で水中振動台を稼働させて, 水 


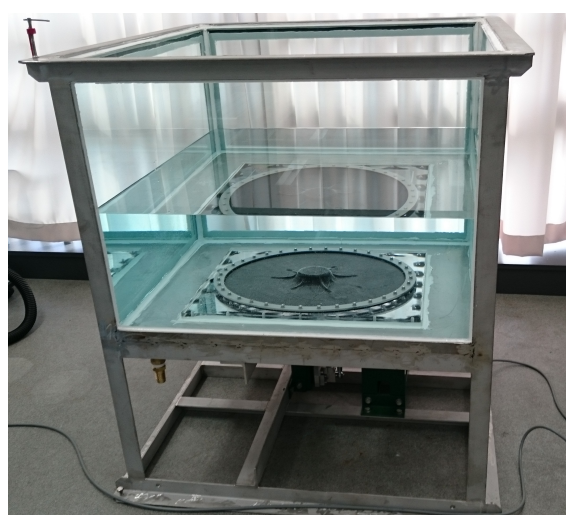

図-4 底面に円形の水中振動台を設置した実験水槽

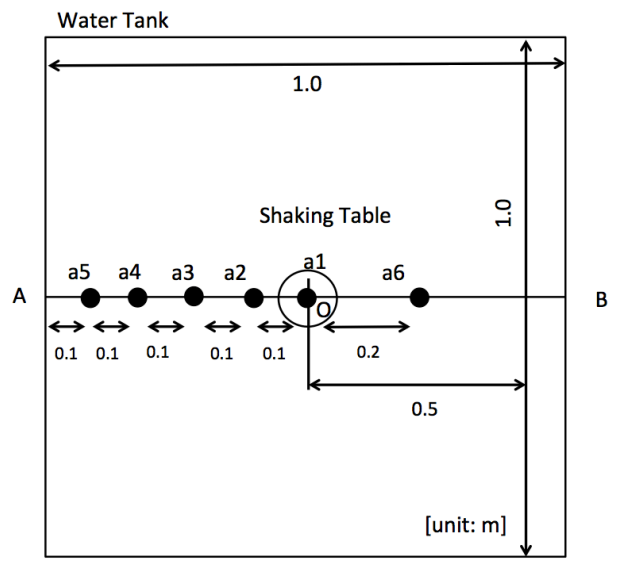

図-5 流速計および水位計，水中振動台の位置

位を計測した。水位計は図一5のa3とa6に設置した。a3お よびa6での水位変動の比較を図-6に示すが，両測定点で の水位波形は一致していることがわかる，また，それぞ れのスペクトル分布を図-7に示すが，いずれの測定点で も水中振動台の振動数に対応した $6 \mathrm{~Hz} の$ 卓越がみられ, 本水理実験の等方性は確認できた。次に，再現性につい て確認するため, 同条件で 2 回実験を実施し，a3での計 測水位を比較した．紙面の都合でグラフは割愛するが, 両実験の水位波形は一致していた。また，いずれのスペ クトル分布でも振動台の振動数に対応した $6 \mathrm{~Hz}$ 占越し ており，本水理実験での再現性は高いことを確認した.

(3) 振動数, 振幅および水深に関するパラメータスタデ 1

パラメータスタディの例として，水中振動台の振動数 が異なる場合の実験結果を比較する. 水深を $30 \mathrm{~cm}$, 水 中振動台の振幅を $3 \mathrm{~cm}$ と，振動数が $4 \mathrm{~Hz}$ および7Hzのケ 一スでの水位変動のスペクトル分布を図-8および図-9に 示す. どちらのケースも水中振動台の振動数に対応した 振動数の卓越が確認できた. しかし，4Hzのケースでは 実験水槽の固有振動に対応した $1.2 \mathrm{~Hz}$ のスペクトルの卓 越が発生していたが，振動数を7Hzとしたケースではみ

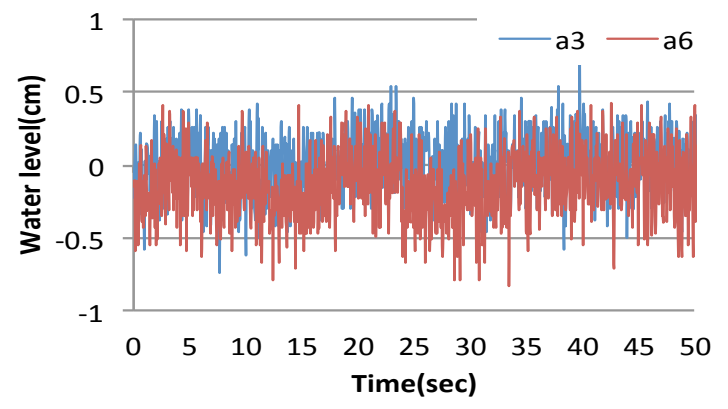

図-6 水位変動の時間変化

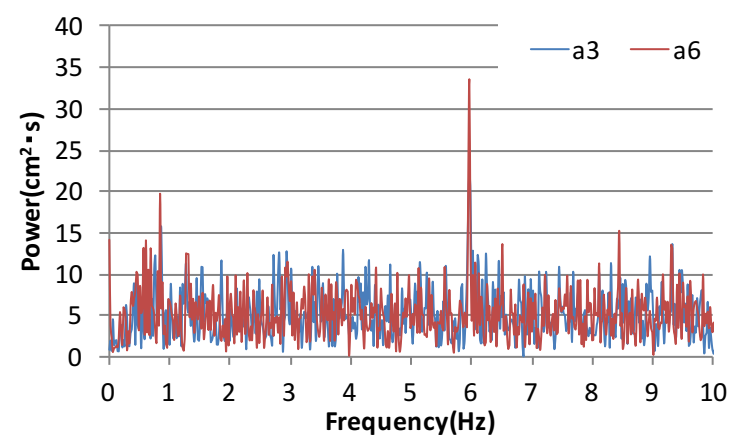

図-7 水位のスペクトル分布

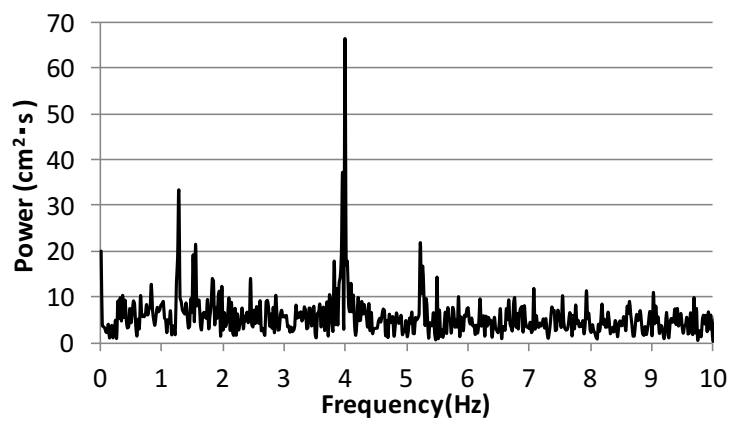

図-8 水位のスペクトル分布（水深 $30 \mathrm{~cm} ，$ 振幅 $3 \mathrm{~cm} ，$ 振動数 $4 \mathrm{~Hz}$ )

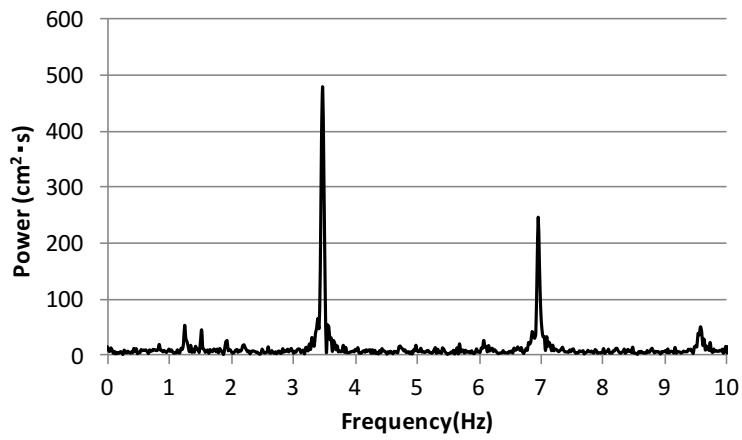

図-9 水位のスペクトル分布（水深 $30 \mathrm{~cm} ，$ 振幅 $3 \mathrm{~cm} ，$ 振動数 $7 \mathrm{~Hz})$

られなかった。また，7Hzのケースではパラメトリック 励振によると考えられる $3.5 \mathrm{~Hz}$ の卓越が発生していたが, 4Hzのケースではみられなかった。 このように，水中振 動台の振動数, その半分の振動数, 実験水槽の固有振動 数の 3 種類の振動数が特徴として現れているが, 前二者 が物理的に有意な現象である.よって，それらについて， 
表-1 水位変動のスペクトル分布の比較

\begin{tabular}{|c|c|c|c|c|c|c|c|c|c|c|}
\hline & \multicolumn{9}{|c|}{ Frequency $(\mathrm{Hz})$} \\
\hline & & 1 & 2 & 3 & 4 & 5 & 6 & 7 & 8 & 9 \\
\hline \multirow{4}{*}{ 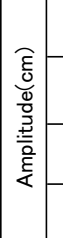 } & 1 & - & - & - & - & - & - & - & - & - \\
\hline & 2 & - & - & - & - & - & - & - & $\Delta$ & 0 \\
\hline & 3 & - & - & - & $\Delta$ & $\Delta$ & 0 & 0 & 0 & 0 \\
\hline & 4 & - & $\Delta$ & - & $\Delta$ & 0 & 0 & 0 & 0 & 0 \\
\hline
\end{tabular}

\begin{tabular}{|c|c|c|c|c|c|c|c|c|c|c|}
\hline \multicolumn{2}{|c|}{ 水深: 50c } & $\mathrm{cm}$ & & & & & & & & \\
\hline & \multicolumn{9}{|c|}{ Frequency $(\mathrm{Hz})$} \\
\hline & & 1 & 2 & 3 & 4 & 5 & 6 & 7 & 8 & 9 \\
\hline \multirow{4}{*}{$\frac{t}{\bar{g}}$} & 1 & - & - & - & - & - & - & - & - & - \\
\hline & 2 & - & $\Delta$ & - & - & - & - & $\Delta$ & $\Delta$ & 0 \\
\hline & 3 & - & $\Delta$ & - & - & - & 0 & 0 & 0 & 0 \\
\hline & 4 & - & $\Delta$ & - & $\Delta$ & 0 & 0 & 0 & 0 & 0 \\
\hline
\end{tabular}

\begin{tabular}{|c|c|c|c|c|c|c|c|c|c|c|}
\hline \multirow{2}{*}{\multicolumn{2}{|c|}{ 水深: 30}} & $\mathrm{~cm}$ & & & & & & & & \\
\hline & & \multicolumn{9}{|c|}{ Frequency $(\mathrm{Hz})$} \\
\hline & 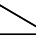 & 1 & 2 & 3 & 4 & 5 & 6 & 7 & 8 & 9 \\
\hline \multirow{4}{*}{ 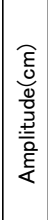 } & 1 & - & - & - & - & - & - & - & $\Delta$ & $\Delta$ \\
\hline & 2 & - & $\Delta$ & $\Delta$ & $\Delta$ & $\Delta$ & $\Delta$ & $\Delta$ & 0 & 0 \\
\hline & 3 & - & $\Delta$ & $\Delta$ & $\Delta$ & $\Delta$ & 0 & 0 & 0 & 0 \\
\hline & 4 & - & $\Delta$ & $\Delta$ & $\Delta$ & $\Delta$ & 0 & 0 & 0 & 0 \\
\hline
\end{tabular}

全実験ケースの測定結果を整理した（表-1）。水中振動 台の振動数（F）とその半分の振動数（1/2F）の卓越が 測定されたケースを $\bigcirc, F に$ 対応した振動数の卓越のみ が測定されたケースを $\triangle$, いずれの振動数の卓越も測定 されなかったケースを一で示している，また，水中振動 台の稼働初期では現れていなくても，時間の経過に伴い 発生する振動があるため, 稼働時間により場合分けを行 った．水中振動台の稼働時間が25.6秒以内に発生した場 合は黒色, 25.6秒以降51.2秒以内に発生した場合は赤色, 51.2 秒以降102.4秒以内に発生した場合は青色で示した. なお, 逆に, 時間経過に伴い消失した場合もあるため, そのケースは緑色でセルを塗りつぶしている.

全体的な傾向としては，水深が小さいほど，また水中 振動台の振幅が大きいほど水中振動台の振動数に対応し た振動が卓越していることがわかる.これは水中振動台 の運動が水面まで伝達しや寸いためと考えられる．また， 水中振動台の振動数が大きいほど，水面でも同様の振動 が発生しや寸いことがわかる，パラメトリック励振によ ると考えられる $1 / 2$ 振動数については, 水中振動台の振 動数や振幅が大きいほど，また稼働時間が長いほど発生 しや寸いことがわかる，なお，渡部らりによる実験では より低い振動数でも $1 / 2$ 振動数が発生している.これは 直径 $6 \mathrm{~m}$ の水中振動台を用いて, より広い範囲で振動を 加えたためと考えられる. よって, 震源域が広域になる 巨大地震ほど, 海面擾乱が発生しや寸い可能性がある.

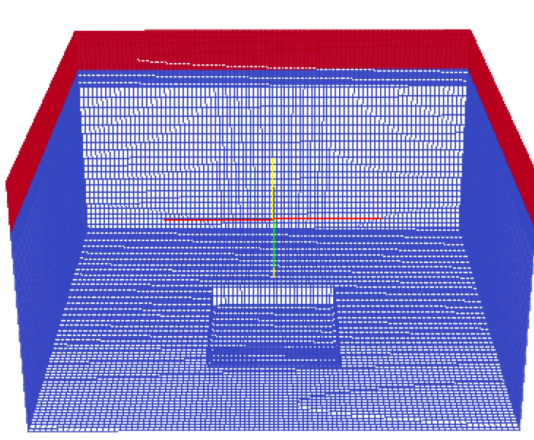

図-10ＯpenFOAMで再現した実験水槽

\section{3 次元数値計算}

\section{(1) 数値モデルの概要}

OBS1 観測点付近での海面擾乱を調べるため, 3 次元 での数值計算を実施した. なお, 数值モデルを実スケー ルに適用する前に, 水理実験結果を用いて再現性の検証 を行っている. 数值モデルとしては OpenFOAM を採用 し，VOF 相比率に基づいた界面捕獲法による不混和流 体の非圧縮性等温 2 相流用 InterDyMForm ソルバを使用 した。図-10に実験水槽を再現した計算領域を示す，底 面中央には振動域を設けた．また，赤色で示している部 分は気相，青色で示している部分は液相である．境界条 件は完全反射とした.

\section{(2) 水理実験結果の再現}

数值モデルの計算精度の確認を行うため, 前述の水理 実験結果の再現を行った．図-10 に示した計算領域は縦 横それぞれ $1 \mathrm{~m}$, 高さ $0.7 \mathrm{~m}$ であり，底面には $10 \mathrm{~cm}$ 四方の 正方形の振動台を設置している. なお，水理実験では水 中振動台の形状は円形であるが，振動台中心の直上での 水面擾乱を比較しているため, 形状の違いの影響は小さ いと仮定している．実験ケースとしては，水中振動台の 振動数に対応したスペクトルが卓越した水深 $30 \mathrm{~cm}$, 水 中振動台の振幅 $3 \mathrm{~cm}$, 振動数 $4 \mathrm{~Hz}$ の条件, また水中振動 台の振動数とその $1 / 2$ 振動数が卓越した水深 $50 \mathrm{~cm}$, 水中 振動台の振幅 $3 \mathrm{~cm}$, 振動数 $6 \mathrm{~Hz}$ の条件を対象とした.

前者の水理実験結果とOpenFOAMにより計算した水位 波形を図-11，それらのスペクトル分布を図-12に示す.

図-11より，計算された水位波形の振幅や周期は水理実 駼結果と同様の傾向を示していることがわかる. また，

図-12より, 計算においても水中振動台の振動数と同様 の $4 \mathrm{~Hz}$ の卓越がみられている. 次に, 後者の条件での水 理実験結果とOpenFOAMにより計算した水位波形を図一 13，それらのスペクトル分布を図-14に示寸. 図-13より, 水理実験結果にみられる約40秒以降の水位の増幅は計算 では再現できていないが，それ以前の波形についてはよ 


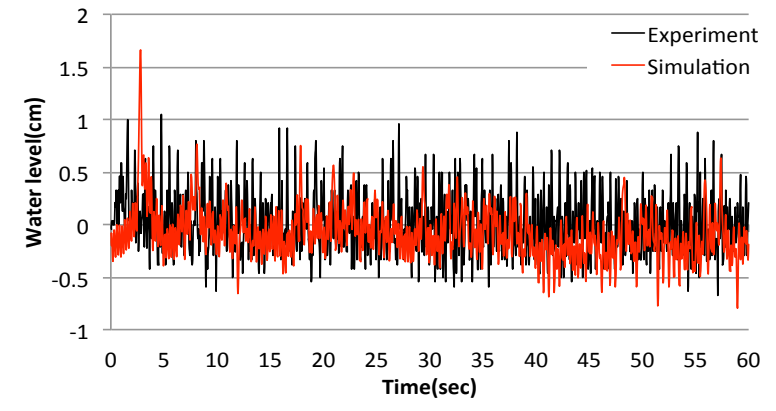

図-11 水位変動の時間变化（水深 $30 \mathrm{~cm}$, 振幅 $3 \mathrm{~cm}$, 振動数 $4 \mathrm{~Hz})$

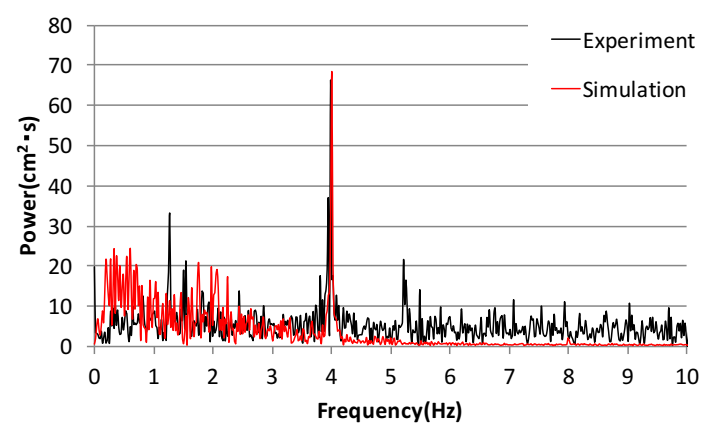

図-12 水位のスペクトル分布（水深 $30 \mathrm{~cm}$, 振幅 $3 \mathrm{~cm}$, 振動数 $4 \mathrm{~Hz})$

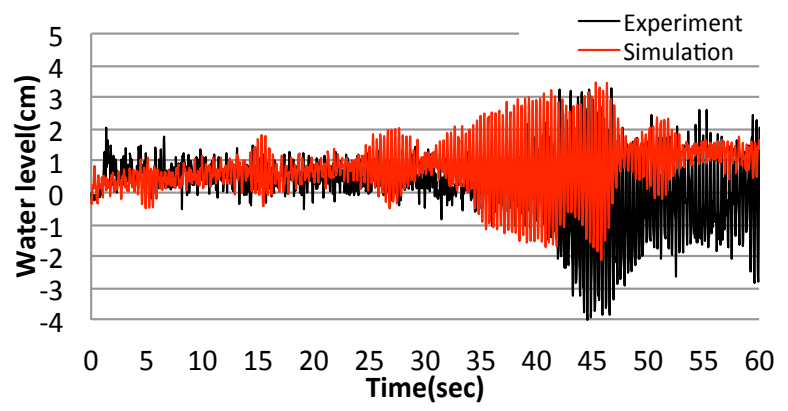

図-13 水位変動の時間变化（水深 $50 \mathrm{~cm}$, 振幅 $3 \mathrm{~cm}$, 振動数 $6 \mathrm{~Hz})$

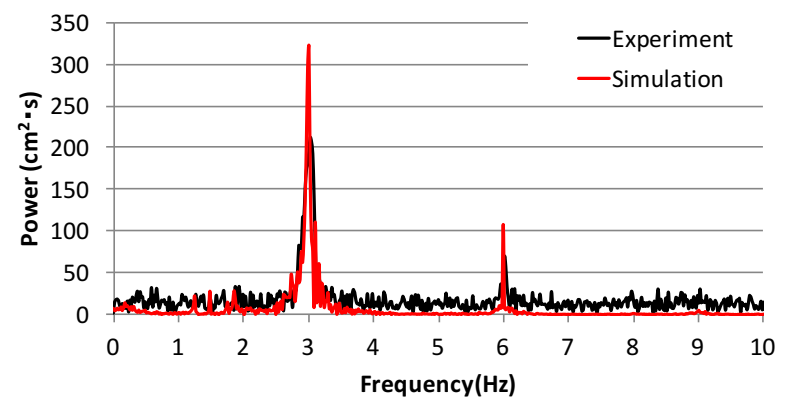

図-14 水位のスペクトル分布（水深 $50 \mathrm{~cm}$, 振幅 $3 \mathrm{~cm}$, 振動数 $6 \mathrm{~Hz})$

く一致していることがわかる，また，水理実験では25秒 以降にファラデー共鳴が発生しているが，図-15に示す ように数值計算においても同様の水面変動が再現できて いる，さらに，図-14のスペクトル分布では，水理実験 で発生している水中振動台の $1 / 2$ 振動数を計算でも再現 できており，本数值モデルの計算精度は十分に高いと判 断できた.

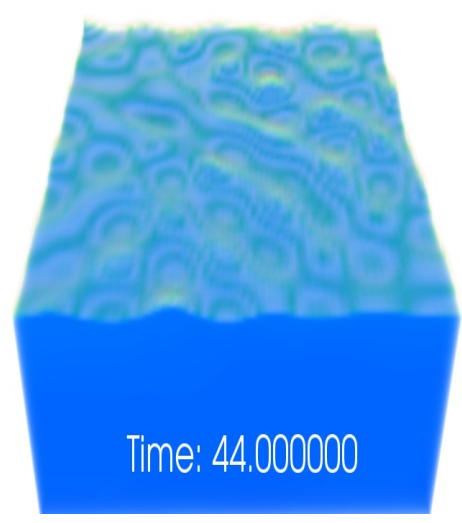

図-15 ファラデー共鳴発生時の水面

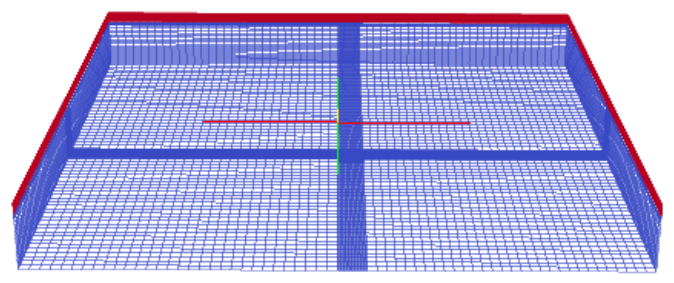

図-16 OpenFOAMで再現した実海域モデル

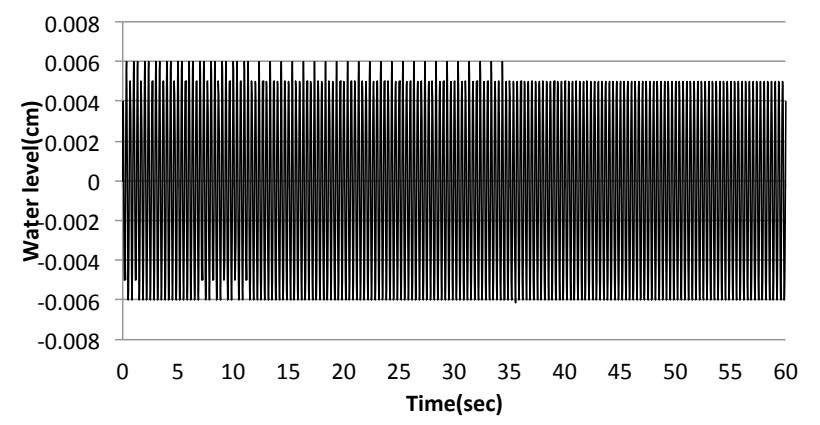

図-17 水位変動の時間変化（水深 $2000 \mathrm{~m}$ ，振幅 $0.03 \mathrm{~m}$, 振動数 $3 \mathrm{~Hz})$

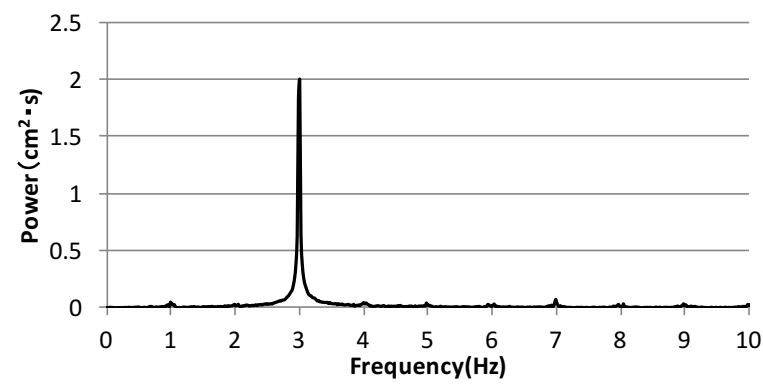

図-18 水位のスペクトル分布（水深 $2000 \mathrm{~m}$, 振幅 $0.03 \mathrm{~m}$, 振動 数 $3 \mathrm{~Hz}$

\section{(3) OBS1 観測付近での海面擾乱の再現}

図-16に示した計算領域は縦横それぞれ $21000 \mathrm{~m} ，$ 水深 $2000 \mathrm{~m}$ であり, 底面中央に $1000 \mathrm{~m}$ 四方の震源域を仮定し た. 入力波形はOBS1が観測したP波を再現するために, 震源域の振動数は図-3でスペクトルが最大になった $3 \mathrm{~Hz}$ とし，振幅は図-2の加速度を2回時間積分して得られた 最大の $0.03 \mathrm{~m} と し た 。$ 計算時間は60秒とした. 震源直上 
の水位波形を図-17，その時のスペクトル分布を図-18に 示す. 図-17より, この時の海面変動は最大で $0.01 \mathrm{~cm}$ と 極めて小さいことがわかる. OBS1は東北地震震源域の 北縁部にあることから, 海底変動量が小さく, P波によ る海面への影響も小さくなったと考えられる. ただし， 図-18より，この時のスペクトル分布は入力波に対応し た $3 \mathrm{~Hz}$ の卓越がみられており，実海域でもP波に対応し た海面擾乱が発生する可能性を示している.

\section{5.おわりに}

巨大地震のP波によって発生する海面擾乱は，海洋レ 一ダによる津波波源観測の指標として用いることが期待 される. そこで，水理実験と 3 次元数值計算を実施して， 急激な底面振動が水面に与える影響について調べた。

まず海底地震計が観測した東北地震の地震波形からP 波を抽出し，P波の振幅と振動数を明らかにした。これ らの情報を基にして，水中振動台を備えた実験水槽を開 発し，水理実験を実施した。 その結果，水深が小さいほ ど，また水中振動台の振動数と振幅が大きいほど，水中 振動台の振動数に対応した水面擾乱が発生しやすいこと を明らかにした. また，水中振動台の振動数と振幅が大 きいほど，また稼働時間が長いほど，パラメトリック励 振と考えられる水面擾乱が発生しやすいことを明らかに した. 3 次元数值計算ではOpenFOAMを採用し，まず水 理実験結果を検証データとして計算精度の確認を行った. 次に実スケールでの数值実験を行い，P波と同じ振動数 を震源域に与えたところ，P波と同様の振動数の海面擾 乱が発生することを明らかにした。ただし，今回設定し たP波の振幅は $3 \mathrm{~cm}$ と小さいため, 今後は大すべり域や 超大すべり域を想定した大振幅による海面擾乱を検討す
る必要がある.また，泉宮らつで考察されているように 鉛直共鳴による水位増幅を考慮することも重要である.

謝辞：本研究の一部は総務省 SCOPE（受付番号 165011003）の委託を受けて行われました. また，東京 大学地震研究所の酒井慎一准教授より地震波形データの 提供をして頂きました。 ここに記して感謝申し上げます。

\section{参考文献}

1) 日向博文, 藤良太郎, 藤井智史, 藤田裕一, 花田弘, 片 岡智哉, 水谷雅裕, 高橋智幸: 紀伊水道における短波海洋 レーダを用いた津波・副振動観測, 土木学会論文集 B2(海 岸工学), Vol.68, No.2,pp.196-200, 2012.

2) Barrick, D. E. : A coastal radar system for tsunami warning, Remote Sensing of Environment, Vol.8, pp.353-358, 1979.

3) 門廻充侍, 高橋智幸: 海洋レーダを用いた南海トラフで の津波波源および伝播観測の適地選定, 土木学会論 文集 B2(海岸工学), Vol.71，No.2, pp.343-348, 2015.

4) 佐藤孫七:海振の話し, 気象 12.2 .

5) 渡部裕太, 高橋智幸, 菅野高弘: 急激な底面変動により水 面に発生する高周波成分に関する水理実験, 海洋開発論 文集，第 23 巻,pp.111-116,2007.

6) 藤井雄士郎, 佐竹健治: 2011 年 3 月 11 日東北地方太平洋 沖地震の津波モデル， http://iisee.kenken.go.jp/staff/fujii/OffTohokuPacific2011/tsunami_ja.ht $\mathrm{ml}$, 参照 2016-03-30.

7) 泉宮尊司, 阿部宏之: 海水の圧縮性と鉛直共鳴による 海面変動の増幅メカニズム, 海岸工学論文集, 第 43 巻, pp.421-425, 1996.

(2016.3.16受付)

\section{Hydraulic Experiment and Numerical Modeling on Disturbances of Surface Velocity and Water Surface Elevation in Tsunami Sources}

\section{Takehiro FUJIHARA, Masashi SAKAMOTO and Tomoyuki TAKAHASHI}

The Oceanographic radar can observe tsunami propagation and its seiche as shown by Hinata et al ${ }^{1)}$. Condequently, an observation of tsunami sources by the Oceanographic radar is expected, because it enables to improve the reliability of tsunami warning and to search terrible disaster areas promptly. A feasibility of the observation depends on understanding of surface velocity and water surface elevation in tsunami sources. This study focused sea surface disturbances caused by P-wave of great earthquakes, and a hydraulic experiment and a numerical modeling were conducted to investigate them. The hydraulic experiment showed that parametric excitation and oscillation corresponding to frequency of shaking table were generated on the water surface. And the numerical modeling showed the sea surface distrurbances according to frequency of P-wave. 